\title{
Topoisomerase-I Inhibitor
}

National Cancer Institute

\section{Source}

National Cancer Institute. Topoisomerase-I Inhibitor. NCI Thesaurus. Code C1904.

Any substance that inhibits topoisomerase-I, a topoisomerase that relieves torsional

stress in a DNA molecule by cutting only one strand of the DNA double helix. Inhibition of topoisomerase-I causes DNA damage, inhibition of DNA replication, and apoptosis. 